\title{
13. CENOZOIC PLANKTONIC FORAMINIFERA FROM ANTARCTIC DEEP-SEA SEDIMENTS, LEG 28, DSDP
}

\author{
Ansis G. Kaneps, Scripps Institution of Oceanography, La Jolla, California
}

\section{INTRODUCTION}

In general, the degree of our knowledge of the stratigraphic distribution of planktonic foraminifer assemblages and their species composition is an inverse function of geographic latitude. Whereas the lower latitude faunas have been extensively studied, those of the high-latitude oceanic regions, especially around Antarctica, have remained virtually unknown. This has been due mainly to the inaccessibility of older sediments to piston coring and other sampling techniques prior to the Deep Sea Drilling program. Leg 28, the first venture of Glomar Challenger into extremely high southern latitudes, thus promised to be a unique opportunity to study the history of high-latitude planktonic foraminifers and how it has been influenced by the associated environmental parameters of low temperature and high nutrient levels and associated high phytoplankton productivity. Another aim would be to determine how long these environmental conditions have existed and if they have changed with time.

The results were, unfortunately, somewhat disappointing. Foraminifers occur sporadically in the Antarctic sections cored during Leg 28; where present, they make up a minor portion of the microfossil assemblage and are of very low diversity. In addition, most assemblages show the effects of carbonate dissolution. The drill sites in the Ross Sea, which might have been expected to yield less dissolved assemblages, are mostly barren of planktonic foraminifers, apparently for paleoenvironmental reasons.

Nevertheless, two general conclusions seem warranted on the basis of Leg 28 results. (1) Antarctic foraminifer assemblages have had a characteristically polar aspect since the Oligocene. That is, they are of extremely limited diversity, and some of the species present are morphologically similar to Globigerina pachyderma (Ehrenberg), which is presently the dominant species in high-latitude waters. (2) The major change in planktonic foraminifer ecology in the Antarctic area took place at or near the Eocene-Oligocene boundary. This is evidenced by the recovery of a diverse upper Eocene assemblage at Hole 267B, at $59^{\circ}$ south latitude which is in marked contrast to the sparseness of younger faunas. This change is most likely related to the initiation of glacial conditions on Antarctica (see General Synthesis, Hayes and Frakes, this volume).

Leg 28 drill sites in the Antarctic are shown in Figure 1 , and site data are given in Table 1. Site 264, the first Leg 28 site, was drilled on the Naturaliste Plateau, close to port. It was primarily a test site to check the operation of the drill rig and is not included in the present report; a discussion of the planktonic foraminifers at this site can be found in the site report for Site 264 (Chapter 2), and in the report by Kennett (this volume). A distribution chart of planktonic foraminifers at this site is given in Table 2 of the present report.

Distribution charts of planktonic foraminifers are given for Sites 265 and 266 in Tables 3 and 4, respectively. Occurrence data for the other sites $(267-274)$ are given at the end of this chapter in the form of species lists. Selected species are illustrated in Plates 1 and 2.

\section{COMPARISON TO PREVIOUS WORK}

Tertiary foraminifer assemblages from the subantarctic Pacific Ocean (north of the Antarctic Convergence) have been described by Riedel and Funnell (1964) and Margolis and Kennett (1971). Margolis and Kennett have, in addition, constructed a paleoenvironmental curve for the Southern Ocean based on trends in foraminifer diversity, expressed as the number of species present. Their results indicate low diversity in the Oligocene which increases to a maximum in the middle Miocene. Although the assemblages seen in the present study are in general less diverse than those from north of the Antarctic Convergence, they exhibit a probable identical diversity pattern. The lower Oligocene assemblage consists of a single species. This increases to two higher in the Oligocene, two to occasionally four in the lower Miocene, and four in the middle Miocene. Upper Miocene assemblages (not recorded by Margolis and Kennett, 1971) have mostly been destroyed by dissolution, but the two samples from which foraminifers were recovered contained one species each. Pliocene assemblages in general are monospecific, while the Pleistocene shows two diversity peaks, one in the lower Pleistocene and one in the upper Pleistocene.

\section{SUMMARY OF ANTARCTIC FAUNAS BY AGE}

The following section outlines the general nature of the recovered faunas by age. Not surprisingly, a number of the species seen in Antarctic sediments were originally described from Tertiary rocks of New Zealand. Except in a broad sense, the planktonic foraminifers were not found useful for age determination; for Leg 28 reliance was placed on the siliceous fossil groups (radiolarians, diatoms, and silicoflagellates).

\section{Eocene (Determinations by P.N. Webb)}

An upper Eocene planktonic fauna was recovered in Core 10 of Hole 267B. It includes Chiloguembelina cubensis (Palmer), C. martini (Pijpers), Catapsydrax echinatus Bolli, Globigerina (Subbotina) linaperta Finlay, G. (S.) angiporoides Hornibrook, Globorotalia (Turborotalia) spp., ?Globigerapsis index (Finlay), and a single broken specimen of Hantkenina sp. (perhaps $H$. 


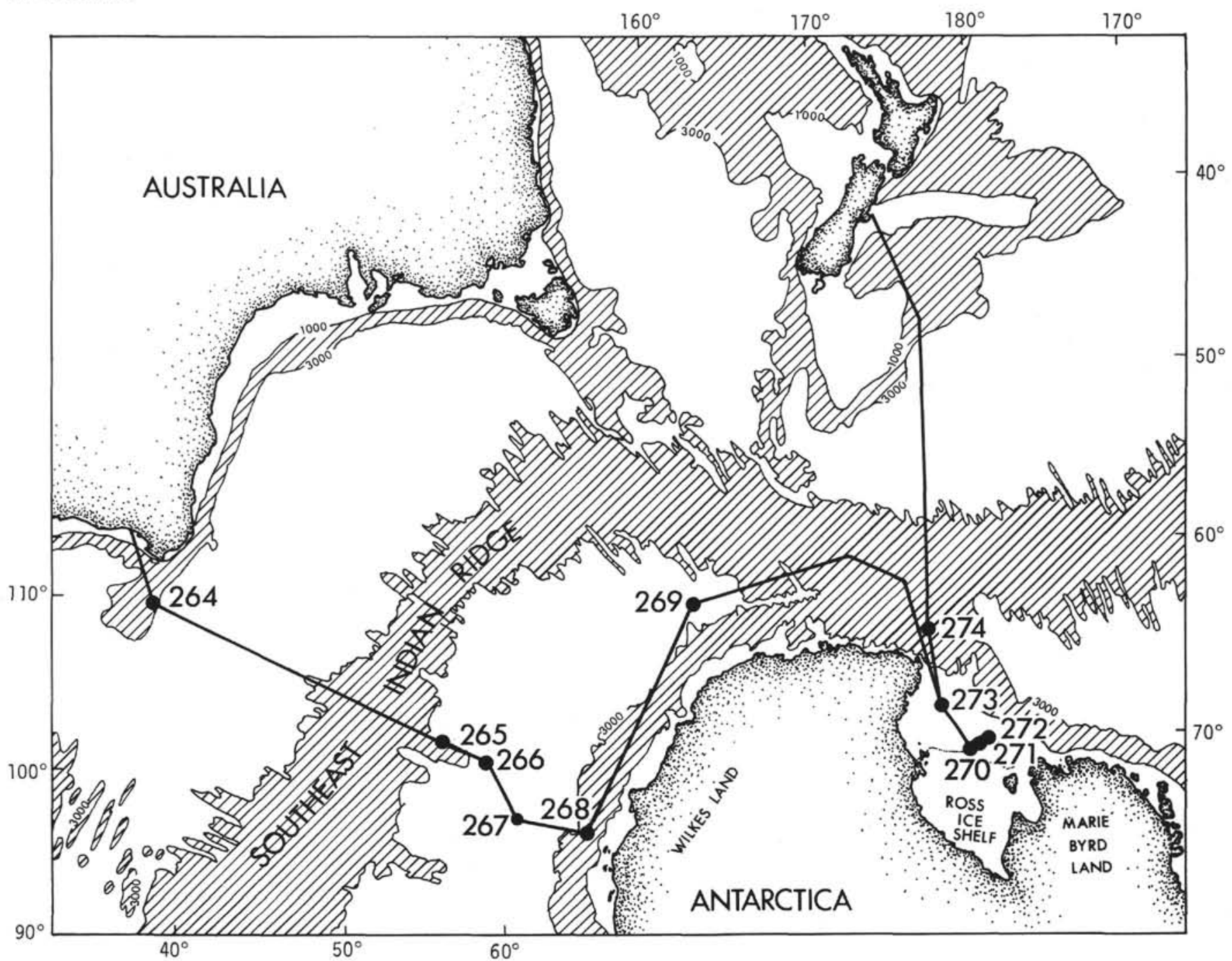

Figure 1. Location map of sites drilled during DSDP Leg 28.

alabamensis compressa Parr). This fauna is notable for its high diversity as compared to Oligocene and younger assemblages.

TABLE 1

Site Data

\begin{tabular}{|c|c|c|c|}
\hline Site & Latitude & Longitude & Water Depth (m) \\
\hline 264 & $34^{\circ} 58.13$ 'S & $112^{\circ} 02.68 \mathrm{E}$ & 2873 \\
\hline 265 & $53^{\circ} 32.45^{\prime} \mathrm{S}$ & $109^{\circ} 56.74^{\prime} \mathrm{E}$ & 3582 \\
\hline 266 & $56^{\circ} 24.13^{\prime} \mathrm{S}$ & $110^{\circ} 06.70^{\prime} \mathrm{E}$ & 4173 \\
\hline $267,267 \mathrm{~A}$ & $59^{\circ} 15.74 \mathrm{~S}$ & $104^{\circ} 29.30^{\prime} \mathrm{E}$ & 4564 \\
\hline 267B & $59^{\circ} 14.55 \mathrm{~S}$ & $104^{\circ} 29.94^{\prime} \mathrm{E}$ & 4539 \\
\hline 268 & $63^{\circ} 56.99$ 'S & $105^{\circ} 09.34^{\prime} \mathrm{E}$ & 3544 \\
\hline 269 & $61^{\circ} 40.57^{\prime} \mathrm{S}$ & $140^{\circ} 04.21 \mathrm{E}$ & 4285 \\
\hline 270 & $77^{\circ} 26.48^{\prime} \mathrm{S}$ & $178^{\circ} 30.19^{\prime} \mathrm{W}$ & 634 \\
\hline 271 & $76^{\circ} 43.27^{\prime} \mathrm{S}$ & $175^{\circ} 02.86^{\prime} \mathrm{W}$ & 554 \\
\hline 272 & $77^{\circ} 07.62^{\prime} \mathrm{S}$ & $176^{\circ} 45.61 \mathrm{~W}$ & 629 \\
\hline 273 & $74^{\circ} 32.29^{\prime} \mathrm{S}$ & $174^{\circ} 37.57^{\circ} \mathrm{E}$ & 495 \\
\hline 274 & $68^{\circ} 59.81^{\prime} \mathrm{S}$ & $173^{\circ} 25.64^{\prime} \mathrm{E}$ & 3326 \\
\hline
\end{tabular}

\section{Oligocene}

The characteristic element of Oligocene Antarctic assemblages is Globigerina angiporoides Hornibrook. As pointed out by Hornibrook (1965) in the original description of this species, there is considerable variation in the size and shape of the final chamber. In the present specimens, it ranges in degree of inflation from a bulla to a normal, full-sized chamber (see Plate 1). In addition, the shape of the aperture ranges from a low slit (in the majority of specimens) to a high arch.

G. angiporoides was found in Cores 5 and 6 of Site 267, and Core 21 of Site 274. In Core 5 of Site 267 Catapsydrax dissimilis (Cushman and Bermudez) was also found. This is the only other species recorded from Leg 28 Oligocene assemblages. Although there is no way to determine the degree of dissolution these assemblages have undergone, the specimens appear to be fairly well preserved (see Plate 1). Thus, the low diversity probably reflects original faunal composition.

\section{Miocene}

\section{Lower Miocene}

Lower Miocene assemblages are slightly more diverse than those of the Oligocene. Their characteristic element 
TABLE 2

Distribution of Planktonic Foraminifers at Site 264

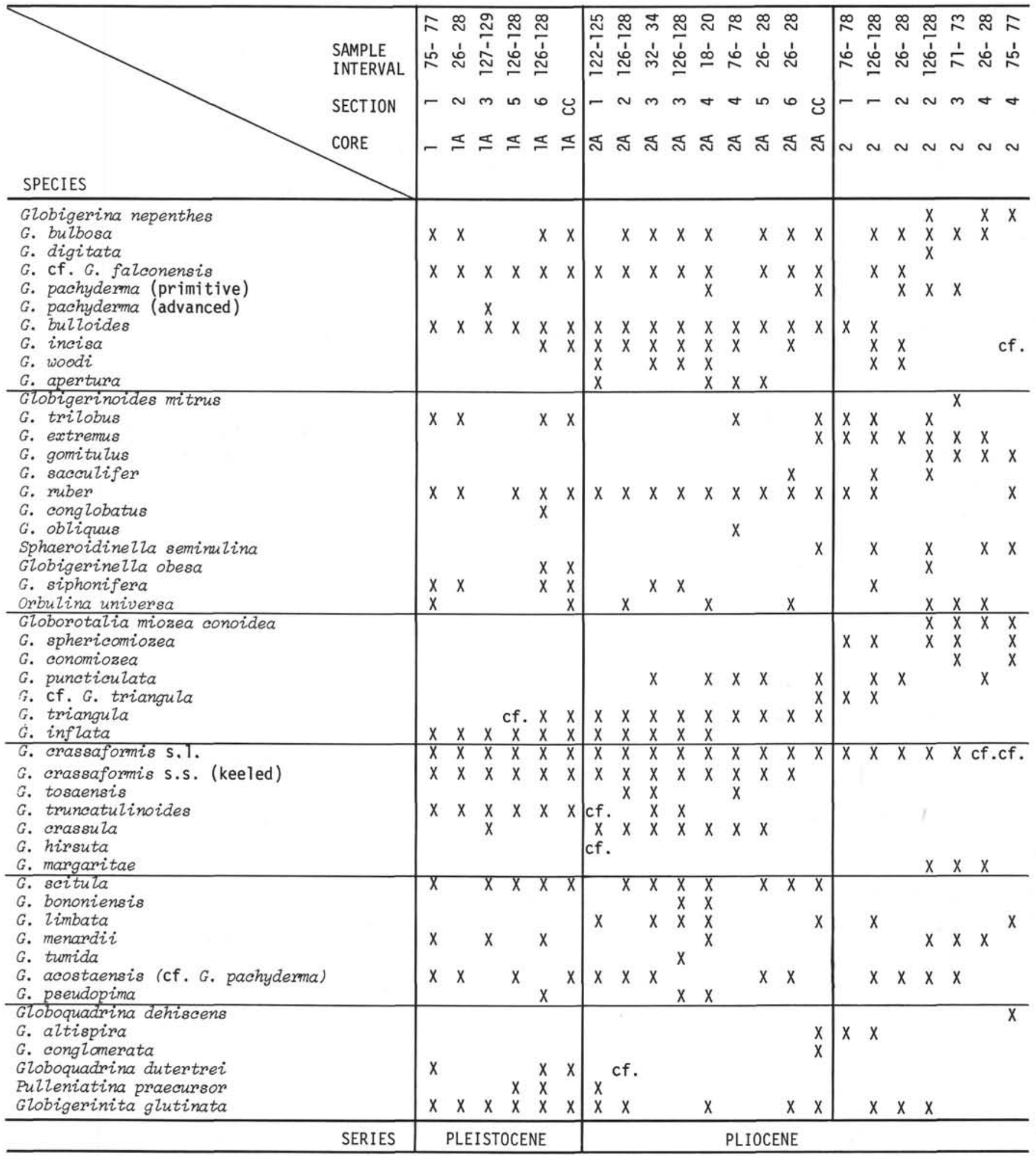


TABLE 3

Distribution of Planktonic Foraminifers and Other Components of the Coarse Fraction at Site 265

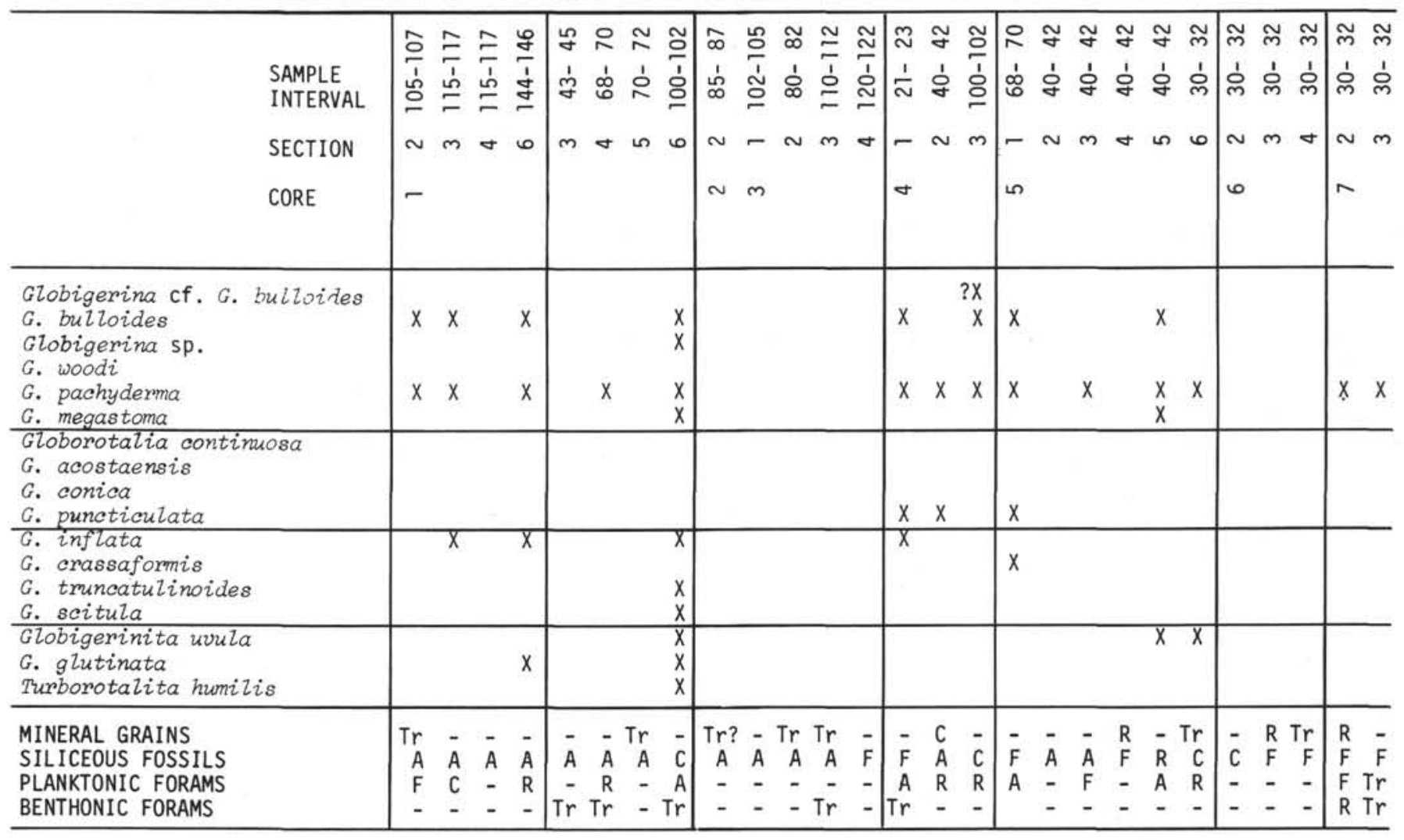

*probably contamination

is Catapsydrax dissimilis (Cushman and Bermudez), which ranges nearly to the top of the lower Miocene. $C$. dissimilis is accompanied through most of the lower Miocene by Catapsydrax unicavus Bolli, Loeblich, and Tappan. The latter disappears at a level somewhat lower than the last occurrence horizon of $C$. dissimilis. Other species that occur sporadically in the lower Miocene are Globorotalia zealandica Hornibrook, Globigerina sp. cf. $G$. woodi Jenkins, Globorotaloides suteri Bolli, and Globigerina sp. cf. G. bulloides d'Orbigny.

It should be noted that $C$. dissimilis seems to have an extended stratigraphic range in the Antarctic as compared to the lower latitude areas from which it was originally described. In warm-water sequences its upper limit is in the mid-lower Miocene while at Site 266 it ranges to nearly the top of the lower Miocene. This seems reasonable in view of its cosmopolitan nature and tolerance for cold-water masses. This has significance in that the $C$. dissimilis last occurrence datum is common to several zonal schemes. On the basis of the present results, however, it appears that this datum may slope stratigraphically upward toward the poles.

\section{Middle Miocene}

Middle Miocene assemblages were recovered at Sites 265 and 266. The species composition differs at the two sites. This is probably a result of age difference, as the foraminifer-bearing sediments at Site 265 are younger than those at Site 266, according to the siliceous fossils.
However, paleoenvironment may also be a factor since the sites have a north-south separation of about $260 \mathrm{~km}$.

The common element in both assemblages is Globigerina woodi Jenkins. Site 266, the higher latitude site, and the older assemblage, contains, in addition, a species of Globorotalia that most closely resembles $G$. miozea Finlay, but is more compact. The younger middle Miocene of Site 265 is more diverse, containing in addition to $G$. woodi, Globigerina bulloides, Globigerinita uvula (Ehrenberg), Globorotalia conica Jenkins, Globorotalia continuosa Blow, and Globigerina sp.

\section{Upper Miocene}

Upper Miocene sediments were recovered at Sites 265 and 266. At Site 265 the upper Miocene is represented by only one sample in which a specimen of Globigerinita uvula was found. At Site 266, the upper Miocene, though thicker, is mostly barren; a specimen of Globigerina similar to Globorotalia continuosa was found in one sample. The scarcity of foraminifers in the upper Miocene can most likely be attributed to calcite dissolution.

\section{Pliocene}

Pliocene assemblages were seen only at Site 265 . Except for a single occurrence of Globorotalia puncticulata Deshayes, the fauna consists solely of Globigerina pachyderma, the species which presently lives in this area. 
TABLE 3 - Continued

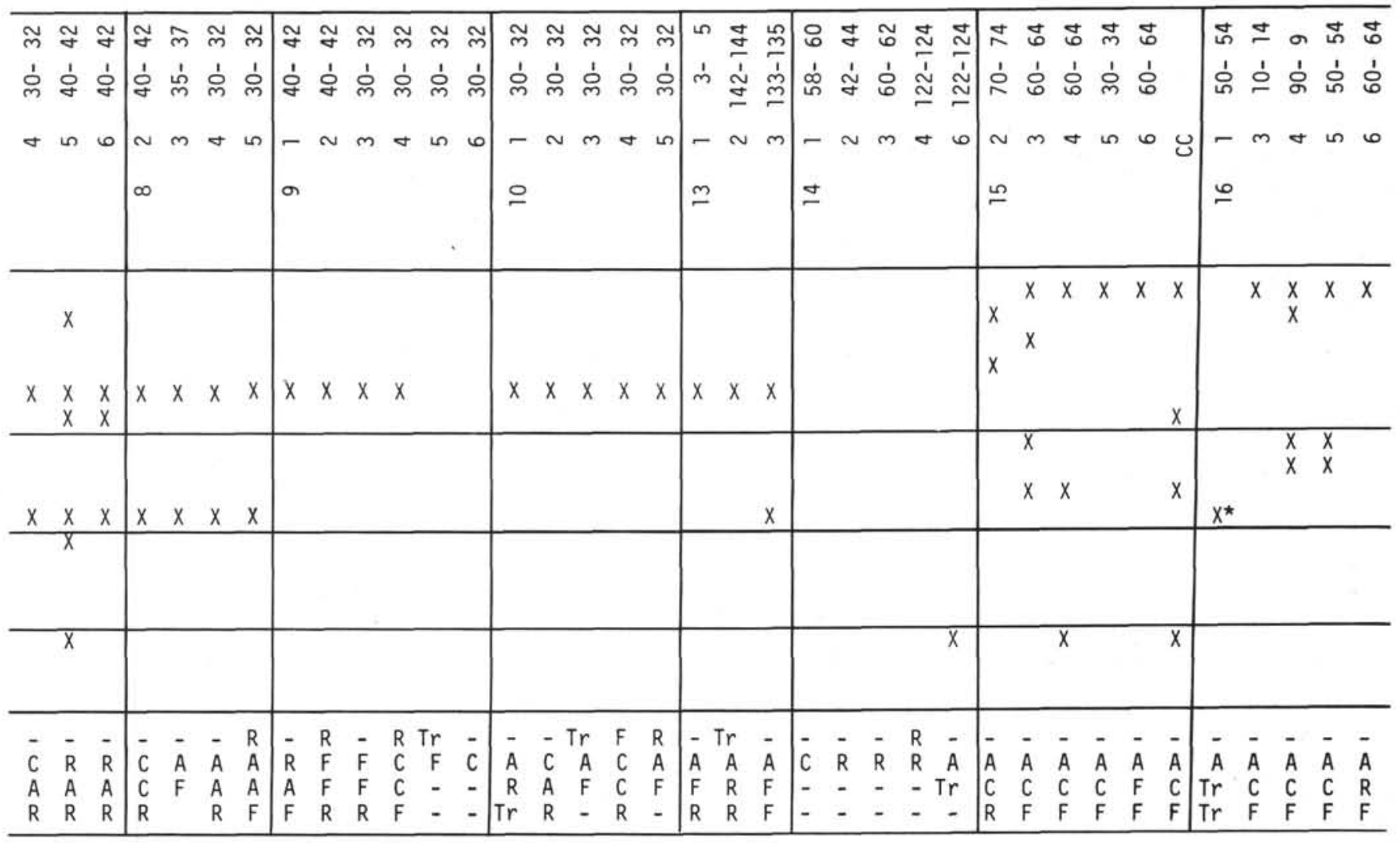

\section{Pleistocene}

The Pleistocene assemblages of Site 265 are on the whole more diverse than those of the Pliocene. Two diversity peaks occur: one in the middle lower Pleistocene, and another in the middle upper Pleistocene (Table 3 ). Found along with $G$. pachyderma, the most common species, are $G$. bulloides, Globigerinita uvula, $G$. quinqueloba Natland, and Globorotalia inflata (d'Orbigny). In addition, lower latitude forms such as Globigerinita glutinata (Egger), Turborotalita humilis (Brady), Globorotalia scitula (Brady), and G. truncatulinoides (d'Orbigny) occur in the mid-upper Pleistocene diversity peak, indicating an expansion of mid-latitude water masses at this time. This foraminifer diversity peak occurs in the lower part of the Emiliania huxleyi nannofossil Zone and thus is somewhat younger than 170,000 y. (Gartner, 1973). Its correlative may be the interglacial X Zone of Ericson et al. (1961), indicating a significant expansion of warmer water masses at this time.

At Site 266, only three Pleistocene samples contain planktonic foraminifers, and in each case the only species present is $G$. pachyderma.

\section{OCCURRENCE OF FORAMINIFERS AT SITES 267-274}

The following isolated occurrences of planktonic foraminifers were noted at Sites 267 through 274. Insofar as could be determined on the basis of core-catcher samples, and other samples which were reported by the shipboard sedimentologists to contain carbonate, the remainder of the sections are barren. Some of these occurrences represent the processing of up to $0.5 \mathrm{~kg}$ of sediment and testify to the general scarcity of foraminifers in circum-Antarctic deep-sea sediments. It would be hoped that future drilling in a shallower area such as the Kerguelen Plateau might overcome the dissolution problem and add materially to our knowledge of Antarctic planktonic foraminifers.

\section{Site $\mathbf{2 6 7}$}

Core 5, CC: Globigerina angiporoides, Catapsydrax dissimilis (Age: mid-Oligocene)

Core 6, CC: Globigerina angiporoides (Age: midOligocene)

Core 10B, CC: Chiloguembelina cubensis (Palmer), C. martini (Pijpers), Catapsydrax echinatus Bolli, Globigerina (Subbotina) linaperta Finlay, G. (S.) angiporoides Hornibrook, Globorotalia (Turborotalia) spp., ?Globigerapsis index (Finlay), and a single broken specimen of Hantkenina sp. (perhaps $H$. alabamensis compressa Parr). (Determinations by P.N. Webb). (Age: upper Eocene)

\section{Site 268}

Core 1: Globigerina pachyderma (Age: Quaternary)

Core 8, CC: Catapsydrax dissimilis, C. unicavus (Age: lower Miocene) 
TABLE 4

Distribution of Planktonic Foraminifers and Other Components of the Coarse Fraction at Site 266

\begin{tabular}{|c|c|c|c|c|c|c|c|c|c|c|c|}
\hline & $\begin{array}{l}\text { SAMPLE } \\
\text { INTERVAL } \\
\text { SECTION } \\
\text { CORE }\end{array}$ & 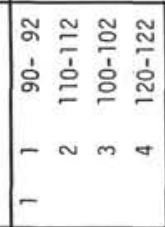 & 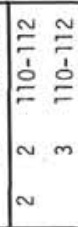 & $=\left[\begin{array}{lll}\cong & \cong & 0 \\
\hdashline & 0 & 0 \\
0 & 0 & 0 \\
0 & 0 & 0 \\
\sim & m & 0 \\
0\end{array}\right.$ & 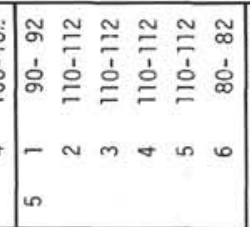 & 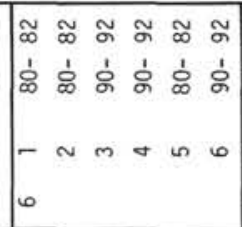 & 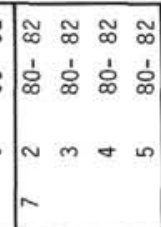 & 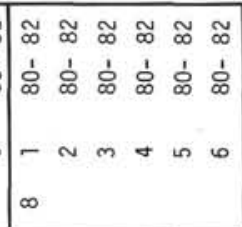 & 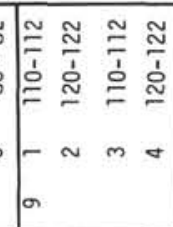 & 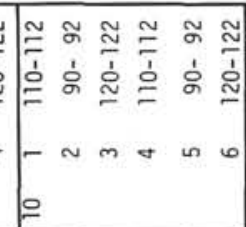 & 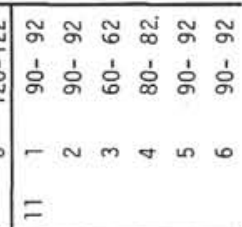 \\
\hline \multirow{2}{*}{\multicolumn{2}{|c|}{$\begin{array}{l}\text { SPECIES } \\
\text { Globigerina pachyderma } \\
\text { G. sp. } \\
\text { G. woodi } \\
\text { G. cf. G. bulloides } \\
\text { G. cf. G. ampliapertura } \\
\text { Globorotalia cf. G. siakensis } \\
\text { G. zealandica } \\
\text { Catapsydrax unicavus } \\
\text { C. dissimilis } \\
\text { Gioborotaloides suteri }\end{array}$}} & 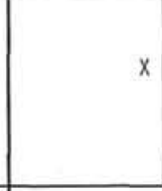 & $x \quad x$ & & & & & & & & $x$ \\
\hline & & & & & & & & & & & \\
\hline \multicolumn{2}{|c|}{$\begin{array}{l}\text { MINERAL GRAINS } \\
\text { SILIIEOUS FOSSILS } \\
\text { PLANKTONIC FORAMS } \\
\text { BENTHONIC FORAMS } \\
\text { INCERTAE SEDIS* }\end{array}$} & $\begin{array}{cccc}F & -T r & - \\
A & A & A & A \\
- & - & - & - \\
-T r & - & - \\
- & - & - & - \\
\end{array}$ & $\begin{array}{ll}-\bar{C} \\
C & A \\
-R & - \\
R & -\end{array}$ & $\begin{array}{lll}- & \text { Tr } & - \\
A & A & A \\
- & - & - \\
- & T r & - \\
- & - & -\end{array}$ & $\begin{array}{|cccccc|}C & A & C & C & A & T r \\
A & A & A & A & A & A \\
- & - & - & - & - & - \\
- & - & T r & - & - & - \\
C & F & F & C & C & C \\
\end{array}$ & $\begin{array}{llllcl}- & - & - & -T r & R \\
A & A & A & A & A & A \\
- & : & - & - & - & - \\
- & - & - & - & - & - \\
R & - & R & - & - & - \\
\end{array}$ & $\begin{array}{rrrr}- & R & T r & R \\
A & A & A & A \\
- & - & - & - \\
- & \bar{C} & \bar{A} & \bar{E} \\
- & C & A & F \\
\end{array}$ & 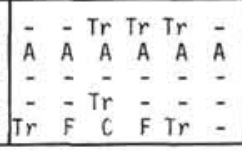 & $\begin{array}{rrrr}- & R & R & ? \\
A & A & A & A \\
-Z & - & - \\
- & - & -T r \\
- & - & - & - \\
\end{array}$ & $\mid \begin{array}{rrrrrr}-\bar{A} & \bar{A} & \bar{A} & - & \mathrm{Ar} & - \\
- & - & - & - & A \\
-T r & - & R & \bar{F} & -\bar{R} \\
- & - & - & - & - & - \\
\end{array}$ & {$\left[\begin{array}{cccccc}T r ? & ? & ? & - & - & - \\
A & A & A & A & A & A \\
\text { Tr } & - & - & - & - & - \\
\text { Tr } & - & - & - & - & - \\
- & - & - & - & - & -\end{array}\right.$} \\
\hline
\end{tabular}

TABLE 4 - Continued

\begin{tabular}{|c|c|c|c|c|c|c|c|c|c|c|c|c|}
\hline & $\begin{array}{l}\text { SAMPLE } \\
\text { INTERVAL } \\
\text { SECTION } \\
\text { CORE }\end{array}$ & 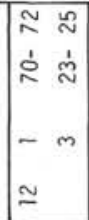 & 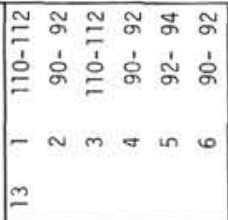 & 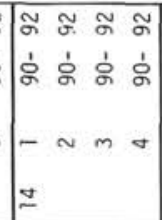 & 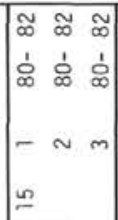 & $\begin{array}{l}0 \\
\vdots \\
\dot{0} \\
0 \\
-\sim \\
\simeq\end{array}$ & 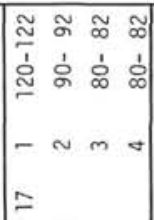 & 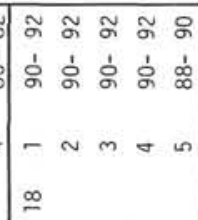 & 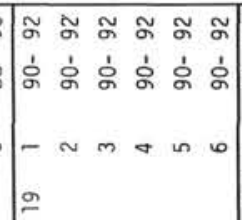 & 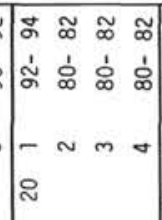 & 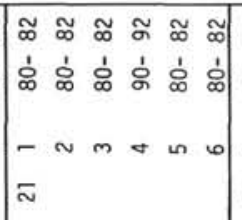 & 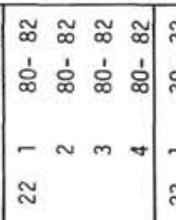 \\
\hline \multirow{2}{*}{\multicolumn{2}{|c|}{$\begin{array}{l}\text { SPECIES } \\
\text { Globigerina pachyderma } \\
\text { G. sp. } \\
\text { G. woodi } \\
\text { G. cf. G. bulloides } \\
\text { G. cf. G. ampliapertiura } \\
\text { Globorotalia cf. G. siakensis } \\
\text { G. zealandica } \\
\text { Catapsydrax unicavus } \\
\text { c. dissimitis } \\
\text { Globorotaloides suteri }\end{array}$}} & & $\begin{array}{lll}x & & x \\
x & x & x\end{array}$ & & & & cf. ${ }^{x}$ & $\begin{array}{c}\text { cf.cf.cf. } \\
x\end{array}$ & & & & $\begin{array}{rrrr} & & & \\
x & x & x & x \\
x & & x \\
\end{array}$ \\
\hline & & & $\begin{array}{llllll}x & x & x & & \\
x & x & x & x & x & x\end{array}$ & & & & 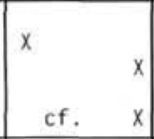 & $\begin{array}{ll}x & x \\
x & x\end{array}$ & 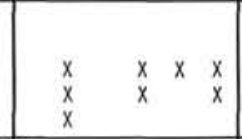 & $\begin{array}{lll}x & x & x \\
x & x & x \\
x & & \end{array}$ & $? \begin{array}{lllll}x & x & x & x & x\end{array}$ & $\left|\begin{array}{llll}x & x & x & x \\
x & & \end{array}\right|$ \\
\hline $\begin{array}{l}\text { MINERAL GRAINS } \\
\text { SILIIIEOUS FOSSILS } \\
\text { PLANTONIC FORAMS } \\
\text { BENTONIC FORAMS } \\
\text { INCERTAE SEDIS* }\end{array}$ & & \begin{tabular}{cc}
$A$ & $A$ \\
\hdashline & - \\
$\operatorname{Tr}$ & $\bar{F}$ \\
- & -
\end{tabular} & $\begin{array}{llllll}C & C & R & - & \bar{A} & - \\
C & C & A & F & A & A \\
R & C & A & F & F & A \\
R & R & & F & F & R \\
- & - & - & - & - & - \\
\end{array}$ & $\left|\begin{array}{llll}A & A & A & A \\
- & - & - & - \\
\hdashline & R & - \\
- & - & -\end{array}\right|$ & $\begin{array}{lll}\bar{A} & \bar{A} & \bar{A} \\
-\bar{z} & \bar{R} & \overline{\mathrm{F}} \\
- & - & -\end{array}$ & $\mid \begin{array}{cc}\bar{A} & - \\
\overline{\text { Tr}} & - \\
- & -\end{array}$ & $\left.\mid \begin{array}{llll}\bar{C} & \bar{A} & \bar{A} & \bar{A} \\
F & R & - & C \\
R & F & R & F \\
- & - & - & -\end{array}\right]$ & $\begin{array}{lllll}\bar{A} & \bar{A} & \bar{A} & \bar{A} & \bar{A} \\
C & C & - & - & R \\
F & F & \bar{F} & \bar{F} & F \\
& - & - & -\end{array}$ & 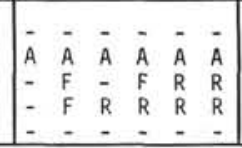 & $\left|\begin{array}{llll}\bar{A} & - & A & - \\
A & A & A & A \\
R & C & C & F \\
R & R & F & R \\
- & - & - & -\end{array}\right|$ & $\left|\begin{array}{cccccc}\bar{A} & \bar{A} & \bar{A} & \bar{A} & \bar{A} & \bar{A} \\
- & R & R & R & R & F \\
T r & R & F & F & R & F \\
T- & F & F & F & R & R\end{array}\right|$ & 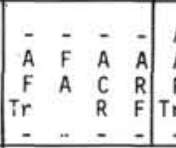 \\
\hline & SERIES & $*$ & MIDDLE MI & IIOCENE & & & & & & LOWER M & & \\
\hline
\end{tabular}

- UPPER MINCENE 
Core 12, CC: Catapsydrax unicavus (Age: lower Miocene)

Core 17, CC: Catapsydrax unicavus (Age: upper middle Oligocene)

Site 269

Core 7A, Section 2, 54-56 cm: Catapsydrax dissimilis (one broken specimen), C. unicavus (Age: Oligocene to lower Miocene)

Core 12A, Section 5, 71-75 cm: ?Globigerina ampliapertura (probably reworked) (Age: ?Oligocene)

Site $\mathbf{2 7 0}$

Core 28, CC: Globigerinoides trilobus (most probably a contaminant from the shipboard laboratory as no other species were found in this sample, and it is highly unlikely that $G$. trilobus has ever lived at the latitude of this site)

Core 34, CC: Chiloguembelina cubensis (Age: ?Oligocene)

Core 36, Section 6, 115-223 cm: Globigerina sp.

Core 39, Section 6, 24-26 cm: Globigerina sp., Globorotalia sp.

\section{Site 271}

Core 1, CC: Globigerina pachyderma (Age: Quaternary)

\section{Site $\mathbf{2 7 2}$}

Insofar as could be determined, the sediments at this site are entirely barren of planktonic foraminifers.
Site 273

Core 4, CC: Globigerina pachyderma, G. megastoma (Age: Quaternary)

Cores 17, 18, CC: Globigerinid, genus and species indet.

\section{Site 274}

Core 21, Section 1, 88-92 cm: Globigerina angiporoides (Age: Oligocene)

Core 21, Section 3, 69-73 cm: Globigerina angiporoides (Age: Oligocene)

\section{REFERENCES}

Ericson, D.B., Ewing, M., Wollin, G., and Heezen, B.C., 1961. Atlantic deep-sea sediment cores: Geol. Soc. Am. Bull., v. 72, p. 193-286.

Gartner, S., 1973. Absolute chronology of the late Neogene calcareous nannofossil succession in the equatorial Pacific: Geol. Soc. Am. Bull., v. 84, p. 2021-2034.

Hornibrook, N. de B., 1965. Globigerina angiporoides n. sp. from the upper Eocene and lower Oligocene of New Zealand and the status of Globigerina angipora Stache, 1865: New Zealand J. Geol. Geophys., v. 8, p. 834-838.

Margolis, S.V. and Kennett, J.P., 1971. Cenozoic paleoglacial history recorded in subantarctic deep-sea cores: Am. J. Sci., v. 271 , p. $1-36$.

Riedel, W.R. and Funnell, B.M., 1964. Tertiary sediment cores and microfossils from the Pacific Ocean floor: Quart. J. Geol. Soc. London, v. 120, p. 305-368. 
A. G. KANEPS

\section{PLATE 1}

Globigerina angiporoides Hornibrook

Figures 1-3 Site 267, Core 5, CC.

1. $\times 185$.

2, 3. $\times 187$.

Figures 4-6 Site 274, Core 21, Section 3, 69-73 cm.

4. $\times 188$.

5. $\times 195$.

6. $\times 183$. 

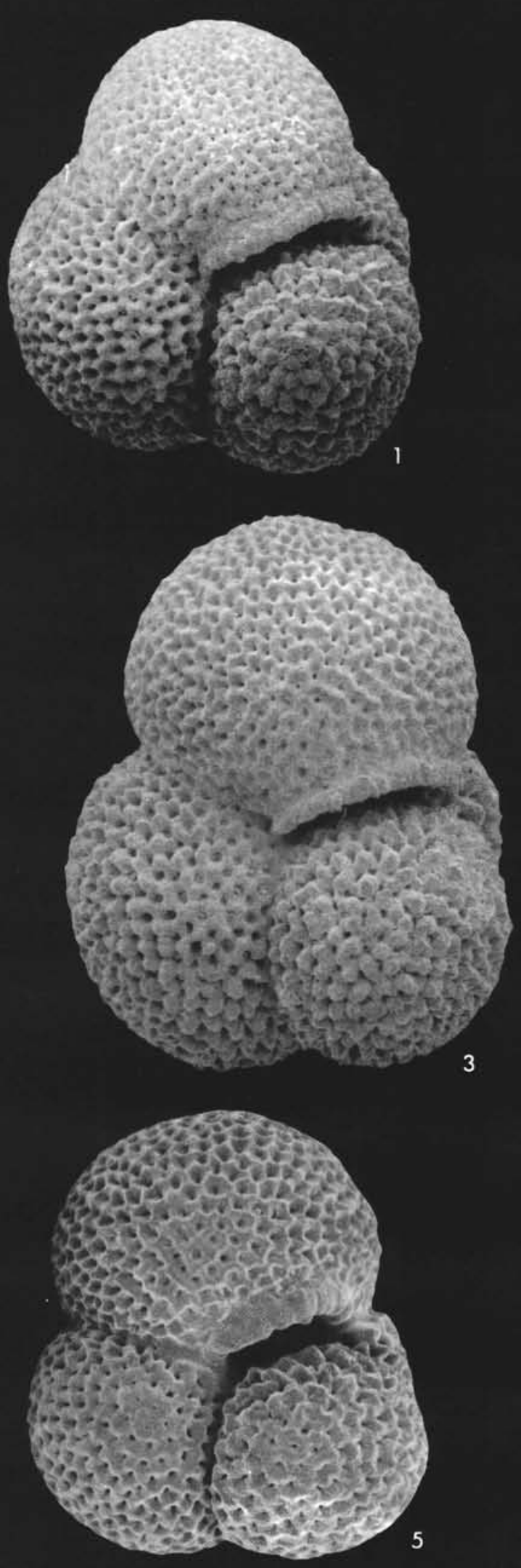
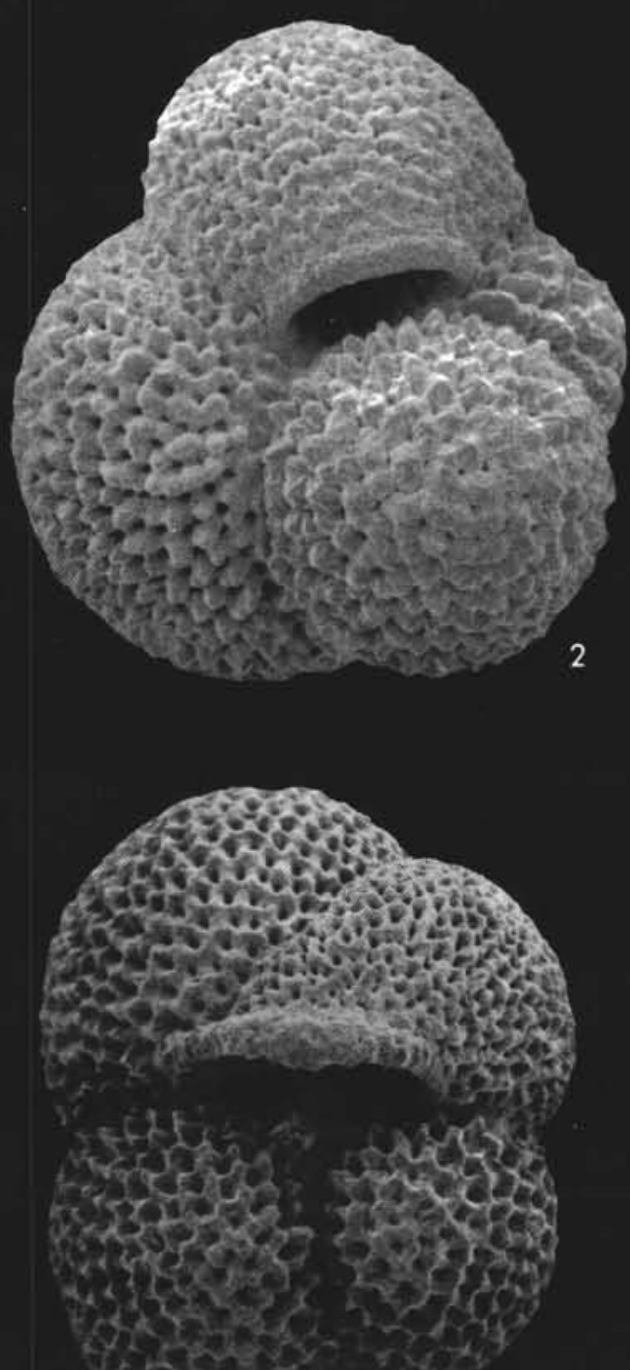

4

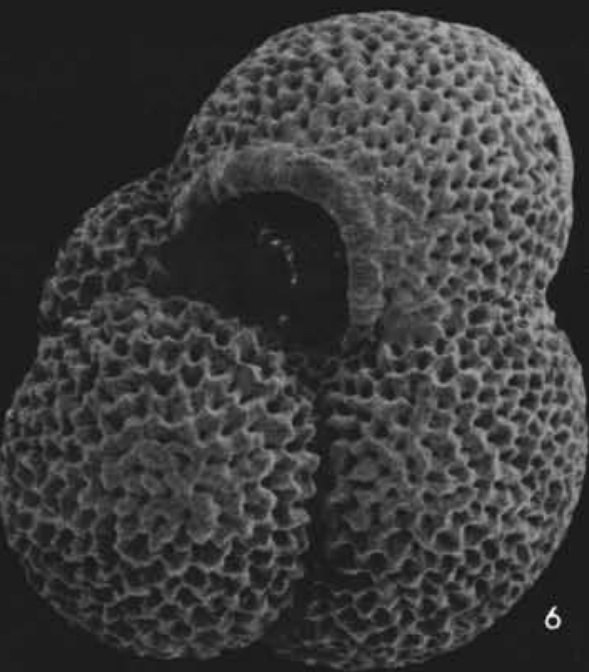




\section{PLATE 2}

Figure 1 Catapsydrax dissimilis (Cushman and Bermudez). Site 267, Core 5, CC. $\times 187$.

Figure $2 \quad$ Globigerina woodi Jenkins.

Site 265 , Core 15 , CC. $\times 195$.

Figures 3-5 Globorotalia conica Jenkins.

Site 265 , Core 15, CC.
3. $\times 212$.
4. $\times 210$.
5. $\times 208$.

Figure $6 \quad$ Globorotalia puncticulata (Deshayes). Site 265, Core 7, CC. $\times 105$.

Figure $7 \quad$ Globigerina pachyderma (Ehrenberg). Site 265, Core 7, CC. $\times 105$.

Figure $8 \quad$ Globigerina megastoma Earland. Site 265, Core 7, CC. $\times 285$.

Figure 9 Globorotalia $s p$.

Site 265 , Core 7, CC. $\times 235$. 

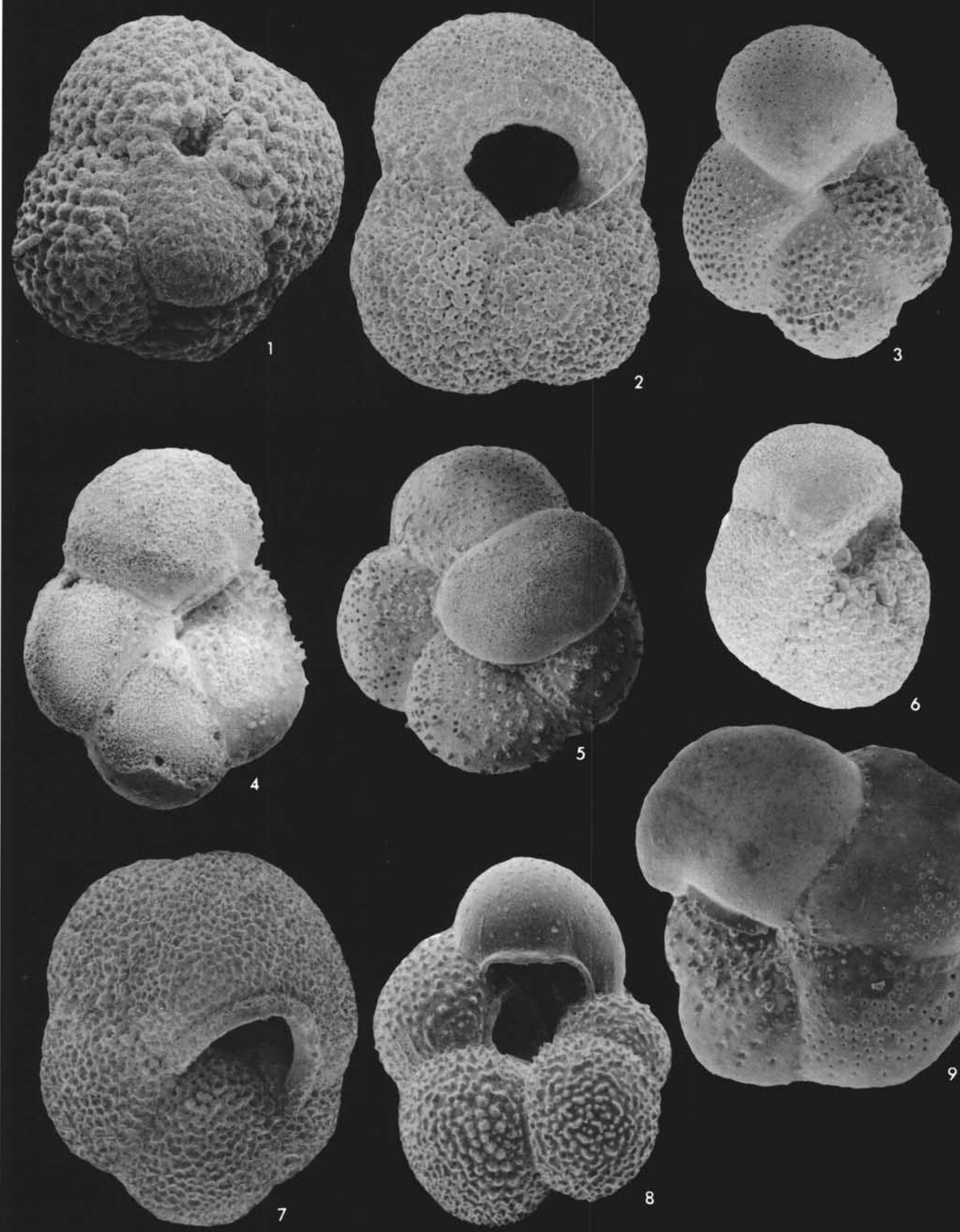